\title{
Management of chemical burn in oral cavity
}

\author{
Mandeep Rallan, ${ }^{1}$ Garima Malhotra, ${ }^{2}$ Neelakshi Singh Rallan, ${ }^{3}$ Sandeep Mayall ${ }^{2}$
}

${ }^{1}$ Department of Pediatric Dentistry, Teerthanker Mahaveer Dental College \& research Centre, Moradabad Uttar Pradesh, India

${ }^{2}$ Depatment of Pedodontics \& Preventive Dentistry,

Teerthanker Mahaveer Dental College \& Research Centre, Moradabad, Uttar Pradesh, India

${ }^{3}$ Department of Oral Pathology \& Microbiology, Teerthanker Mahaveer Dental College \& Research Centre, Moradabad, Uttar Pradesh, India

\section{Correspondence to}

Dr Mandeep Rallan,

drmandeeprallan@gmail.com

\section{DESCRIPTION}

A 7-year-old boy reported to the department of pedodontics and preventive dentistry with the complaint of attached lower lip to the lower gums, difficulties in speaking, eating hot and spicy food and a burning sensation in the underlying mucosa. Upon inspection adhesion of the lower lip to the mandibular anterior vestibule, with a whitish appearance of the underlying mucosa was found. Treatment plan included vestibular deepening followed by non-eugenol surgical dressing and periodontal pack (COE-PAK) for 1 week. After 1 week uneventful healing was noted and the vestibule was no longer attached to the lower lip. Follow-up periods of 1 week, 1 month and 3 months showed complete healing and no reoccurrences of adhesion. Ingestion of caustic material may result in tissue and organ damage leading to a wide range of complications, including loss of functions. ${ }^{1}$ This is dependent on a variety of factors which include strength $(\mathrm{pH})$ or concentration of the material, the quantity ingested, the manner and duration of

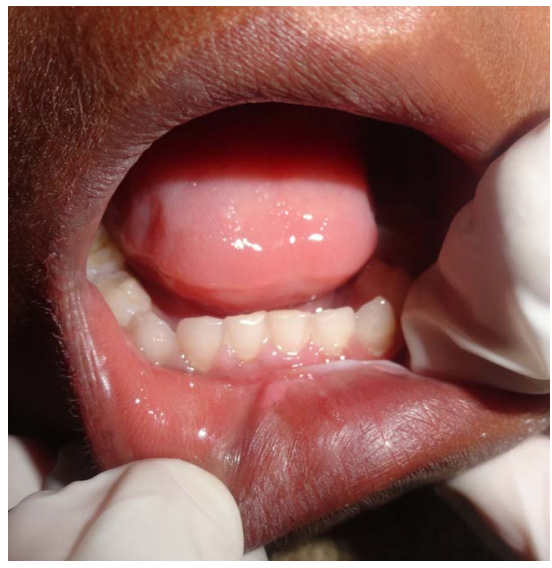

Figure 1 Preoperative.

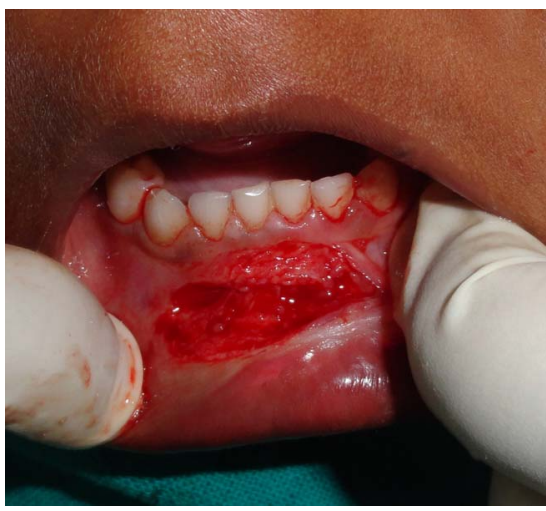

Figure 2 After incision.

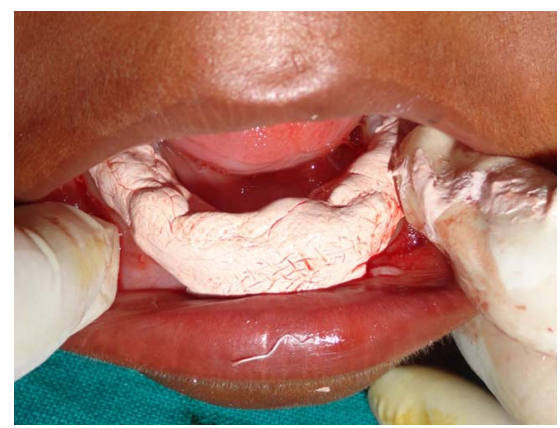

Figure 3 With COE-PAK dressing.

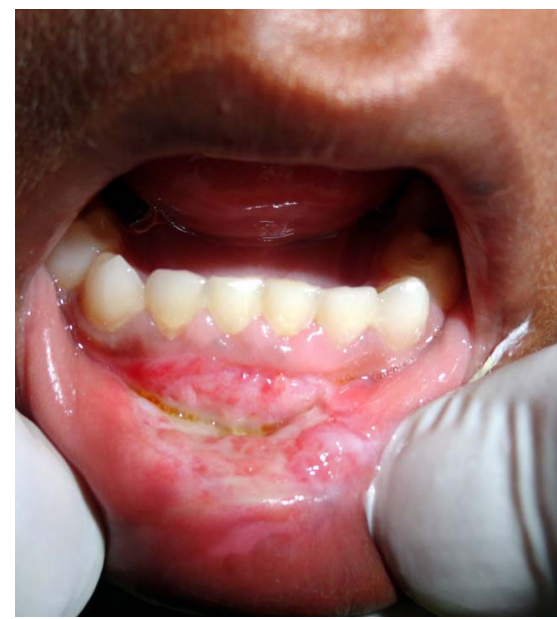

Figure 4 After 1 week postoperative.

tissue contact, the extent of penetration into the tissue and the mechanism of action. ${ }^{2}$ Alkalis are

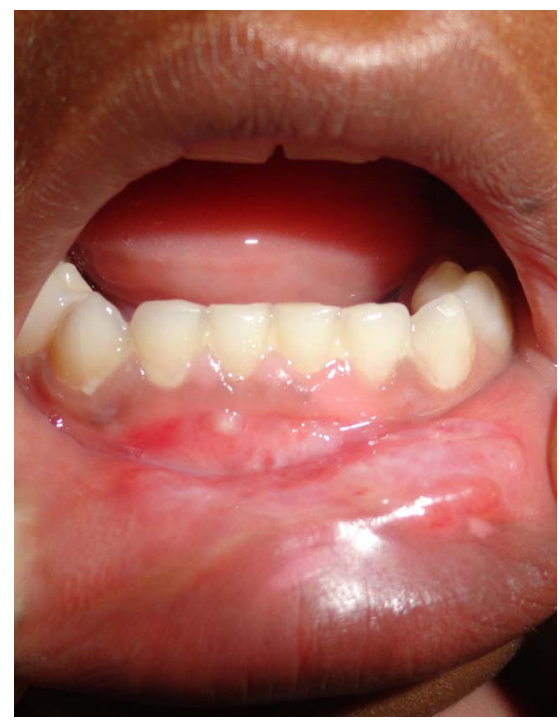

Figure 51 month postoperative. 


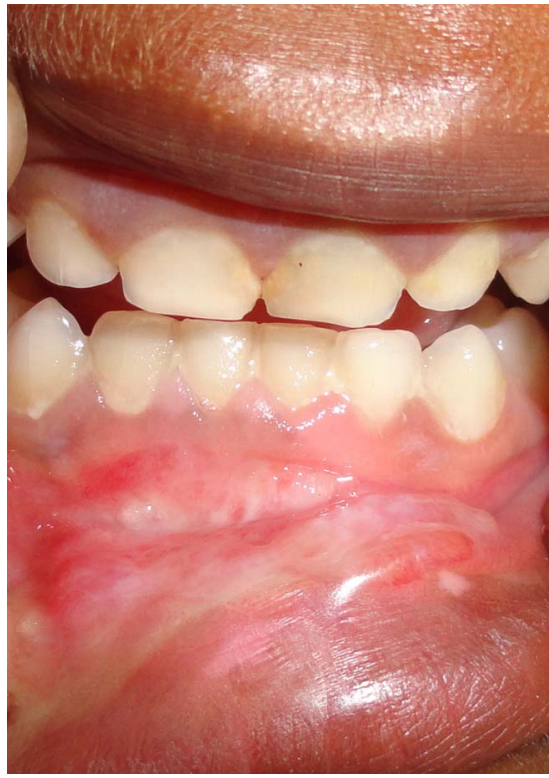

Figure 63 months postoperative.

particularly destructive because of their lytic action on tissues. Various treatment options may be offered to patients with caustic acid ingestion, like topical and intralesional corticosteroids, commissuroplasties, mucosal flaps, free radial forearm flap and free-jejunal graft, ${ }^{1}$ electrocautary and soft tissue laser. Taking into consideration the patient's age, cooperation, financial condition vestibular deepening followed by COE-PAK was opted which shows good results with no reoccurrences (figures 1-6).

\section{Learning points}

After accidental ingestion of chemical:

- Give large quantities of water.

- Induce vomiting.

- In case of shortening of breadth give $\mathrm{O}_{2}$ and seek medical attention.

Competing interests None.

Patient consent Obtained.

Provenance and peer review Not commissioned; externally peer reviewed.

\section{REFERENCES}

1 Kumar S, Rana AS, Gupta D, et al. Unusual presentation of caustic ingestion and its surgical treatment: A case report. J Maxillofac Oral Surg 2011;10:74-6.

2 Manjunath DM, Prakash PG, Madhav SS "Tetracycline hydrochloride burn" as self-inflicted mucogingival injury a rare case report. J Ind Soc Periodont 2012:16:282-5.

Copyright 2013 BMJ Publishing Group. All rights reserved. For permission to reuse any of this content visit http://group.bmj.com/group/rights-licensing/permissions.

BMJ Case Report Fellows may re-use this article for personal use and teaching without any further permission.

Become a Fellow of BMJ Case Reports today and you can:

- Submit as many cases as you like

- Enjoy fast sympathetic peer review and rapid publication of accepted articles

- Access all the published articles

- Re-use any of the published material for personal use and teaching without further permission

For information on Institutional Fellowships contact consortiasales@bmjgroup.com

Visit casereports.bmj.com for more articles like this and to become a Fellow 